\title{
Relationship between Profile of Bt Cotton Growers and their Knowledge and Adoption for Control of Pink Bollworm
}

\author{
A. M. Todkar*, S. R. Jakkawad and S. B. Khodake \\ Department of Extension Education, College of Agriculture, Parbhani (M.S.), India \\ *Corresponding author
}

\section{A B S T R A C T}

\begin{tabular}{l} 
K e y w o r d s \\
$\begin{array}{l}\text { Adoption, } \\
\text { Relationship, } \\
\text { Profile of Bt cotton } \\
\text { growers, Bt. cotton, } \\
\text { Pink bollworm, } \\
\text { Pheromone traps etc }\end{array}$ \\
Article Info \\
$\begin{array}{l}\text { Accepted: } \\
18 \text { November } 2020 \\
\text { Available Online: } \\
10 \text { December } 2020\end{array}$ \\
\hline
\end{tabular}

Keywords

Adoption,

Relationship

Profile of Bt cotton

Pink bollworm,

Pheromone traps etc

Article Info

Accepted:

Available Online:

10 December 2020

\begin{abstract}
Variable like annual income, area under $B t$ cotton, source of irrigation and risk orientation found to be had positive and significant relationship with the knowledge of respondents for control of pink bollworm. While social participation, farming experience, source of information, extension contact, innovativeness, economic motivation found positive and highly significant with knowledge of respondents for control pink bollworm. Whereas variable like age, land holding etc. found non-significant relationship with knowledge of respondents. And education observed to be negatively significant with knowledge of respondents. Variable like education, area under $B t$ cotton, innovativeness and source of irrigation observed to be had positive and significant relationship with the adoption of respondents for control of pink bollworm. While social participation, source of information, extension contact, economic motivation, risk orientation found positive and highly significant with adoption of respondents for control pink bollworm. Where, variable like age, land holding and annual income cotton found non-significant relationship with adoption of respondents. And variable like farming experience is negatively significant with adoption of cotton growers for control of pink bollworm.
\end{abstract}

\section{Introduction}

Cotton (Gossypium spp.) 'king of fiber' which closely linked to the human civilization and economically important germ comprising about 40 species of which four are commercially cultivated for cotton lint and seed. Cotton fiber was discovered more than 4000 years ago in Coastal Peru and MohenjoDaro in the Indus valley. Textile industry contributes 4.00 per cent GDP, 14.00 per cent of total industrial products, 26.00 per cent of total work force, 7.00 per cent share of countries export earnings and 12.00 per cent of world textile production. (GOI, 2014) Control of pink bollworms involves all available techniques for managing pest populations with the aim of reducing pesticide use while maintaining profitability, yield and fiber quality. Crop, insect pests, diseases, natural enemies, cropping practices and patterns and prevalent weather are essentially to be considered simultaneously to improve decision making for profitable and sustainable control. 


\section{Results and Discussion}

The study was conducted in randomly selected Parbhani district of Marathwada region. In Parbhani district there are 9 talukas. out of these three talukas Parbhani, Purna and Pathri was selected randomly as area and infestation of pink bollworm was more in these region. The names of villages which come under the selected talukas were collected from the secondary source. To obtain the desired no of respondent of villages this comes under Parbhani district. Ten $B t$ cotton growers were selected randomly from each village to comprise the sample of 120 respondents for study. Respondents were selected according to the considerable area under $B t$ cotton growers. The study sample consists of having 120 respondents from three talukas. The Data were analyzed by using mean, S.D., and coefficient of correlation methods were used for data analysis.

\section{Observations and analysis}

Coefficient of correlation between profile of $B t$ cotton growers and their knowledge for control of pink bollworm

From the table 1, study were showed that variable like annual income, area under $B t$ cotton, source of irrigation and risk orientation found to be had positive and significant relationship with the knowledge of respondents for control of pink bollworm. While social participation, farming experience, source of information, extension contact, innovativeness, economic motivation found positive and highly significant with knowledge of respondents for control pink bollworm. Whereas variable like age, land holding etc. found non-significant relationship with knowledge of respondents. And education observed to be negatively significant with knowledge of respondents.

Table.1 Correlation coefficient between profile of $B t$ cotton growers and their knowledge for control of pink bollworm

\begin{tabular}{|c|c|c|}
\hline Sr. No. & Independent variables & $\begin{array}{c}\text { Co-efficient of correlation } \\
\text { with knowledge }\end{array}$ \\
\hline $\mathbf{1 .}$ & Age & $0.165 \mathrm{Ns}$ \\
\hline $\mathbf{2}$ & Education & $-0.223^{*}$ \\
\hline $\mathbf{3}$ & Total area under $B t$ cotton & $0.271^{*}$ \\
\hline $\mathbf{4}$ & Land holding & $0.057 \mathrm{Ns}$ \\
\hline $\mathbf{5}$ & Source of irrigation & $0.273^{*}$ \\
\hline $\mathbf{6}$ & Annual income & $0.258^{*}$ \\
\hline $\mathbf{7}$ & Social participation & $0.828^{* *}$ \\
\hline $\mathbf{8}$ & Farming experience & $0.915^{* *}$ \\
\hline $\mathbf{9}$ & Source of information & $0.880^{* *}$ \\
\hline $\mathbf{1 0}$ & Extension contact & $0.636^{* *}$ \\
\hline $\mathbf{1 1}$ & Economic motivation & $0.746^{*}$ \\
\hline $\mathbf{1 2}$ & Innovativeness & $0.879^{* *}$ \\
\hline $\mathbf{1 3}$ & Risk orientation & $0.238^{*}$ \\
\hline
\end{tabular}


Table. 2 Correlation coefficient between profile of Bt cotton growers and their adoption for control of pink bollworm

\begin{tabular}{|c|c|c|}
\hline Sr. No. & Independent variables & $\begin{array}{c}\text { Co-efficient of correlation } \\
\text { with adoption }\end{array}$ \\
\hline $\mathbf{1 .}$ & Age & $0.181 \mathrm{Ns}$ \\
\hline $\mathbf{2}$ & Education & $0.223^{*}$ \\
\hline $\mathbf{3}$ & Total area under $B t$ cotton & $0.212^{*}$ \\
\hline $\mathbf{4}$ & Land holding & $0.091 \mathrm{Ns}$ \\
\hline $\mathbf{5}$ & Source of irrigation & $0.280^{*}$ \\
\hline $\mathbf{6}$ & Annual income & $0.05 \mathrm{Ns}$ \\
\hline $\mathbf{7}$ & Social participation & $0.716^{*} *$ \\
\hline $\mathbf{8}$ & Farming experience & $-0.284^{*}$ \\
\hline $\mathbf{9}$ & Source of information & $0.840^{*}$ \\
\hline $\mathbf{1 0}$ & Extension contact & $0.428^{*} *$ \\
\hline $\mathbf{1 1}$ & Economic motivation & $1.00^{* *}$ \\
\hline $\mathbf{1 2}$ & Innovativeness & $0.273^{*}$ \\
\hline $\mathbf{1 3}$ & Risk orientation & $0.704^{*} *$ \\
\hline
\end{tabular}

Coefficient of correlation between profile of $B t$ cotton growers and their adoption for control of pink bollworm

From the table 2, study observed that variable like education, area under $B t$ cotton, innovativeness and source of irrigation observed to be had positive and significant relationship with the adoption of respondents for control of pink bollworm. While social participation, source of information, extension contact, economic motivation, risk orientation found positive and highly significant with adoption of respondents for control pink bollworm. Where, variable like age, land holding and annual income cotton found nonsignificant relationship with adoption of respondents and variable like farming experience is negatively significant with adoption of cotton growers for control of pink bollworm

In conclusion the research study concluded that, variable like annual income and risk orientation found to be had positive and significant relationship with the knowledge of respondents for control of pink bollworm. While social participation, farming experience, source of information, extension contact, innovativeness found positive and highly significant with knowledge of respondents for control pink bollworm. Whereas variable like age, land holding etc. found non-significant relationship with knowledge of respondents. And education observed to be negatively significant with knowledge of respondents. While area under $B t$ cotton does not found any relationship between knowledge of $B t$ cotton growers for control of pink bollworm. Research study concluded that, variable like education and source of irrigation observed to be had positive and significant relationship with the adoption of respondents for control of pink bollworm. While social participation, source of information, extension contact, economic motivation, risk orientation found positive and highly significant with adoption of respondents for control pink bollworm. Where, variable like age, land holding and annual income cotton found non-significant relationship with adoption of respondents. 
And variable like farming experience is negatively significant with adoption of cotton growers for control of pink bollworm. While area under $B t$ cotton does not found any relationship between adoption of $B t$ cotton growers for control of pink bollworm.

\section{References}

Shashidhara K K, Bheemappa, A, Hirevenkangoudar, L, V. and Shashidhar, K.C. (2007) adoption of drip irrigation management practices by the plantation crop growers. Karnataka journal of agricultural science. 20(1): 79-81.

Shanti Nirmala, V. (2010). A Study on Rythu Chaitanya Yatra A farmer empowerment programme in Mahaboob Nagar district of Andhra Pradesh. M.Sc. (Agri.) Thesis. Acharya N.G. Ranga Agricultural University, Hyderabad, India.
Lad, A. S. (2013). Knowledge and adoption of recommend package of practices of Green gram. M.sc (Agri.) Thesis, Vasantrao Naik Marathwada Krishi Vidyapeeth, Parbhani (M.S.).

Pavan Kumar, P. and Dhorey, R.K. (2017). Extent of Adoption of Farmers about Bt Cotton Practices in Warangal District of Telangana State, India. Int.J.Curr. Microbiol.App.Sci. 6(11): 824-829.

Ambavane, D.N. (2014). Knowledge and adoption of recommended chilli production technology by growers. M.Sc. (Agri Thesis), VNMKV, Parbhani.

Padwal D., Jahanar, M.H., Bose,D.K. and Srivastava J.P. (2018). A study on knowledge of $\mathrm{Bt}$ cotton cultivation practices in Rangareddy district of Telangana. Journal of Pharmacognosy and Phytochemistry, 7(3): 2204-2205.

\section{How to cite this article:}

Todkar, A. M., S. R. Jakkawad and Khodake, S. B. 2020. Relationship between Profile of Bt Cotton Growers and their Knowledge and Adoption for Control of Pink Bollworm. Int.J.Curr.Microbiol.App.Sci. 9(12): 2734-2737. doi: https://doi.org/10.20546/ijcmas.2020.912.326 